\title{
HEIGHTS AND WEIGHTS OF BRITISH BUSINESSMEN
}

\author{
J. F. RICHARDSON, M.B., B.S., AND G. PINCHERLE, M.B., M.R.C.P. \\ Institute of Directors' Medical Centre, Belgrave Square, London, S.W.1.
}

The Institute of Directors' Medical Centre opened in London in June 1964. By the end of October 1968, when the tabulations in this paper were carried out, 12,000 examinations on nearly 8,000 patients had been performed. The full range of the examinations undertaken and some of our earlier findings have been published previously (Pincherle and Wright, 1967; Wright, 1968).

Standing height was measured in stockinged feet using a sliding headpiece. Weight was measured on a lever balance in trousers and dressing gown only (representing 3-4 lb. above nude weight). Subscapular and triceps skinfolds have also been measured since the end of 1965 , and a companion paper on these is in preparation. The data on which this paper is based are restricted to those 4,049 men whose skinfolds were measured on their initial visit.

All coded data were stored on magnetic tape, and a general search programme enabled any desired set of tables to be produced cheaply and simply. The statistical analysis was based on grouped data, the groups being 10-year age intervals, 10-lb. weight intervals, and one-inch height intervals. In all relevant calculations, the centre points of these groups were taken.

\section{RESULTS}

Table I shows mean weights, by age and height, and the number of men on which the estimates are based. The overall mean age was 46.6 years.

The overall frequency distribution of weight in this series was positively skewed (as expected), and there were no great differences with age. Considering only height intervals with more than 200 members in each, i.e., from 66 to 73 in., there was significant skewness to the right at all heights from 66 to 71 in. (significant at least at the 5\% level), but at 72 and 73 in. of height there was no significant skewness. The method used was to calculate the asymmetry index. Details are given in Biometrika Tables (Pearson and Hartley, 1966). It is also worth noting that the very short men (63 in. or less) were heavier than the next group (64 in.).

Table II shows that the mean height fell a little with increasing age, and this was statistically significant (regression coefficient $=0.048$ in./year; $t=3.03 ; \mathrm{P}<0.005)$.

Increasing weight with increasing height was to be expected. Table II shows that the regression coefficients for this relationship were not significantly different in the different age groups. An increase of weight with age was also expected, and

TABLE I

MEAN WEIGHTS (lb.), BY AGE AND HEIGHT

\begin{tabular}{|c|c|c|c|c|c|c|c|c|c|c|c|c|c|}
\hline \multirow{2}{*}{\multicolumn{2}{|c|}{ Height (in.) }} & \multicolumn{12}{|c|}{ Age (years) } \\
\hline & & \multicolumn{2}{|c|}{$<35$} & \multicolumn{2}{|c|}{$35-44$} & \multicolumn{2}{|c|}{$45-54$} & \multicolumn{2}{|c|}{$55-64$} & \multicolumn{2}{|c|}{$65+$} & \multicolumn{2}{|c|}{ All Ages } \\
\hline More than & $\begin{array}{l}63 \\
63 \\
64 \\
65 \\
66 \\
67 \\
68 \\
69 \\
70 \\
71 \\
72 \\
73 \\
74 \\
75 \\
76\end{array}$ & $\begin{array}{l}168 \\
155 \\
140 \\
154 \\
166 \\
155 \\
164 \\
169 \\
174 \\
174 \\
178 \\
186 \\
185 \\
201 \\
207\end{array}$ & $\begin{array}{r}(3) \\
(4) \\
(6) \\
(15) \\
(17) \\
(30) \\
(52) \\
(48) \\
(83) \\
(68) \\
(44) \\
(42) \\
(21) \\
(9) \\
(6)\end{array}$ & $\begin{array}{l}163 \\
149 \\
143 \\
152 \\
157 \\
162 \\
169 \\
175 \\
177 \\
183 \\
188 \\
196 \\
198 \\
203 \\
212\end{array}$ & $\begin{array}{r}(12) \\
(5) \\
(15) \\
(28) \\
(67) \\
(147) \\
(188) \\
(196) \\
(239) \\
(164) \\
(159) \\
(85) \\
(48) \\
(30) \\
(19)\end{array}$ & $\begin{array}{l}155 \\
155 \\
152 \\
159 \\
163 \\
164 \\
172 \\
172 \\
180 \\
183 \\
189 \\
194 \\
191 \\
204 \\
204\end{array}$ & $\begin{array}{r}(16) \\
(6) \\
(29) \\
(51) \\
(104) \\
(150) \\
(183) \\
(206) \\
(209) \\
(166) \\
(119) \\
(60) \\
(38) \\
(14) \\
(9)\end{array}$ & $\begin{array}{l}154 \\
152 \\
149 \\
162 \\
158 \\
167 \\
171 \\
176 \\
180 \\
191 \\
187 \\
190 \\
196 \\
201 \\
201\end{array}$ & $\begin{array}{r}(9) \\
(11) \\
(29) \\
(33) \\
(56) \\
(98) \\
(118) \\
(114) \\
(110) \\
(57) \\
(55) \\
(38) \\
(14) \\
(10) \\
(7)\end{array}$ & $\begin{array}{l}170 \\
155 \\
157 \\
162 \\
158 \\
162 \\
172 \\
171 \\
178 \\
182 \\
185 \\
195 \\
250 \\
-\end{array}$ & $\begin{array}{r}\text { (4) } \\
(1) \\
(6) \\
(10) \\
(10) \\
(17) \\
(7) \\
(7) \\
(6) \\
(8) \\
(1) \\
(1) \\
(2)\end{array}$ & $\begin{array}{l}159 \\
153 \\
149 \\
158 \\
160 \\
164 \\
170 \\
174 \\
178 \\
183 \\
187 \\
193 \\
194 \\
203 \\
208\end{array}$ & $\begin{array}{r}(44) \\
(27) \\
(85) \\
(137) \\
(254) \\
(442) \\
(548) \\
(571) \\
(647) \\
(463) \\
(378) \\
(226) \\
(123) \\
(63) \\
(41)\end{array}$ \\
\hline
\end{tabular}

- Figures in parentheses are the number of men on which the mean weight is based. 
TABLE II

MEAN WEIGHTS AND HEIGHTS RELATED TO AGE

\begin{tabular}{|c|c|c|c|c|c|c|}
\hline & \multicolumn{6}{|c|}{ Age (years) } \\
\hline & $<35$ & $35-44$ & $45-54$ & $55-64$ & $65+$ & Total \\
\hline $\begin{array}{l}\text { No. } \\
\text { Mean height (in.) (H) } \\
\text { Mean weight (lb.) (W) } \\
\text { Regression coefficient (lb./in.) } \\
\text { Mean weight corrected to height of } 69 \cdot 3 \text { in. } \\
\frac{W}{\mathrm{H}^{2}} \times 1000\end{array}$ & $\begin{array}{c}448 \\
69 \cdot 9 \\
172 \cdot 5 \\
3 \cdot 66 \\
170 \cdot 3 \\
35 \cdot 3\end{array}$ & $\begin{array}{c}1402 \\
69 \cdot 7 \\
177 \cdot 1 \\
4.90 \\
175 \cdot 1 \\
36.4\end{array}$ & $\begin{array}{c}1360 \\
69 \cdot 1 \\
175 \cdot 4 \\
3 \cdot 88 \\
176 \cdot 2 \\
36 \cdot 7\end{array}$ & $\begin{array}{c}759 \\
68 \cdot 8 \\
174 \cdot 7 \\
4 \cdot 39 \\
176 \cdot 9 \\
36 \cdot 9\end{array}$ & $\begin{array}{c}80 \\
67 \cdot 3 \\
169 \cdot 3 \\
4 \cdot 27 \\
177 \cdot 8 \\
37 \cdot 4\end{array}$ & $\begin{array}{r}4049 \\
69 \cdot 3 \\
175 \cdot 4 \\
4 \cdot 31 \\
- \\
36.5\end{array}$ \\
\hline
\end{tabular}

All the regression coefficients are significant at the 0.001 level ( $t$ test). The regression coefficients at different ages are not significantly different

the maximum weights in this series were in the 35-44 year age group, after which there was a consistent fall. However, when the mean weights in each age group were adjusted to the overall mean height, using the age specific regression equation or the index

$$
\frac{\mathrm{W}}{\mathrm{H}^{2}} \times 1000
$$

a steady increase of weight with age was apparent. This was particularly true of the difference between the youngest age group (less than 35) and the rest.

The technique of multiple regression analysis was performed on the data and gave the following equation (assuming a linear relationship):

Expected weight $=175.4+4.4$ (height -69.3$)+$ $0 \cdot 18$ (age - 46.6)

Both partial regression coefficients were highly significant $(t>50 \quad P<0.0001)$.

\section{Discussion}

Basically, height is outside the influence of the individual, while weight may be partly controlled by the normal healthy adult. With age, height rises to a maximum variously estimated between 20 and 35 years of age, remains stationary after cessation of growth of the vertebral column until about the age of 45, and then falls (Tanner, 1962; Harrison, Weiner, Tanner, and Barnicot, 1964; Miall, Ashcroft, Lovell, and Moore, 1967). Apart from postural defects, such as lordosis and kyphosis, which may be associated with atrophy of the intervertebral discs (Tanner, 1962), osteoporosis, which in later life occurs in everyone to a greater or lesser degree, may lead to a loss of height. There is evidence to suggest that the overall development of the skeleton at maturity plays a part in determining the future severity of osteoporosis of unknown aetiology, when disease is excluded (Garn, 1967). Our results show a consistent fall in height with increasing age, but the fall is increased after 55 years of age.
It is necessary to stress that this is a cross-sectional study and heights are being compared at different ages, as in most other published series. Only longitudinal studies on the same individuals are likely to give valid information on height changes with age, and eventually we hope to obtain data on this point.

The secular increase of height is well documented. Tanner (1962) quoted a figure of $63 \mathrm{in}$. for the height of an 18-year-old male factory worker in 1833, compared to 69 in. in 1958 in his own series. He estimated this secular increase in Western Europe to be about 1 in. per generation ( 25 years), and this estimate is supported by Khosla and Lowe (1968).

Even when comparing various series produced at similar times, there are differences, such as racial (Ashcroft, Ling, Lovell, and Miall, 1966), environmental (Evans and Prior, 1969), socio-economic, urban-rural, and regional (Martin, 1949), to be considered. With increasing age, there is also a cohort effect due to the survival of the biologically and socially elite. In addition, the prevalence of intercurrent disease varies between different populations at any one time and changes differentially with time.

Table III compares the mean heights by age in our study with two other series published in this country (Kemsley, 1952; Khosla and Lowe, 1967). It is interesting to note that our executives are taller in each age range and, as mentioned previously, the fall in height with increasing age is increased after the age of 55, although this observation is based on small numbers. It seems likely that a secular increase in height is the main factor but that a true fall in height after the age of 55 may contribute to these results. This was also the conclusion reached in a recent longitudinal study carried out in Wales (Miall et al., 1967).

There are appreciable differences between the social classes in their heights and weights, in both adults and children (Clements and Pickett, 1954; 
TABLE III

MEAN STANDING HIEIGHT BY AGE IN BRITISH SERIES

\begin{tabular}{|c|c|c|c|c|c|}
\hline \multirow[b]{2}{*}{ Source } & \multicolumn{5}{|c|}{ Age (years) } \\
\hline & $<35$ & $35-44$ & $45-54$ & $55-64$ & $65+$ \\
\hline $\begin{array}{l}\text { Institute of Directors series } \\
1964-1968 \\
4,049 \text { men }\end{array}$ & $69 \cdot 9$ & 69.7 & $69 \cdot 1$ & 68.8 & $67 \cdot 3$ \\
\hline $\begin{array}{l}\text { Kbosla and Lowe (1967) } \\
1960 \\
5,239 \text { men in Birmingham }\end{array}$ & 68.5 & $67 \cdot 8$ & $67 \cdot 2$ & $66 \cdot 2$ & - \\
\hline $\begin{array}{l}\text { Kemsley (1952) } \\
1943 \\
27,515 \text { civilian men (National) }\end{array}$ & $66.7^{*}$ & $66.4^{\circ}$ & $65.8^{*}$ & $65.4^{\circ}$ & $64 \cdot 7 *$ \\
\hline
\end{tabular}

-1 inch has been subtracted for footwear.

Tanner, 1962). This factor may in part explain the differences shown in Table III, as all of our subjects are now from social classes I and II. Khosla and Lowe (1967), in an industrial population in Birmingham, were able to show a 1.5-in. height difference between the taller monthly paid staff and the wage earners, with the weekly staff in an intermediate position.

The Figure shows the mean weights of our series at each inch of height for the age group 45-54 compared with other series of comparable ages. The regressions of weight on height for different nationalities and races are very nearly parallel (Kemsley, Billewicz, and Thomson, 1962) and our data are no exception. The men in our series are heavier

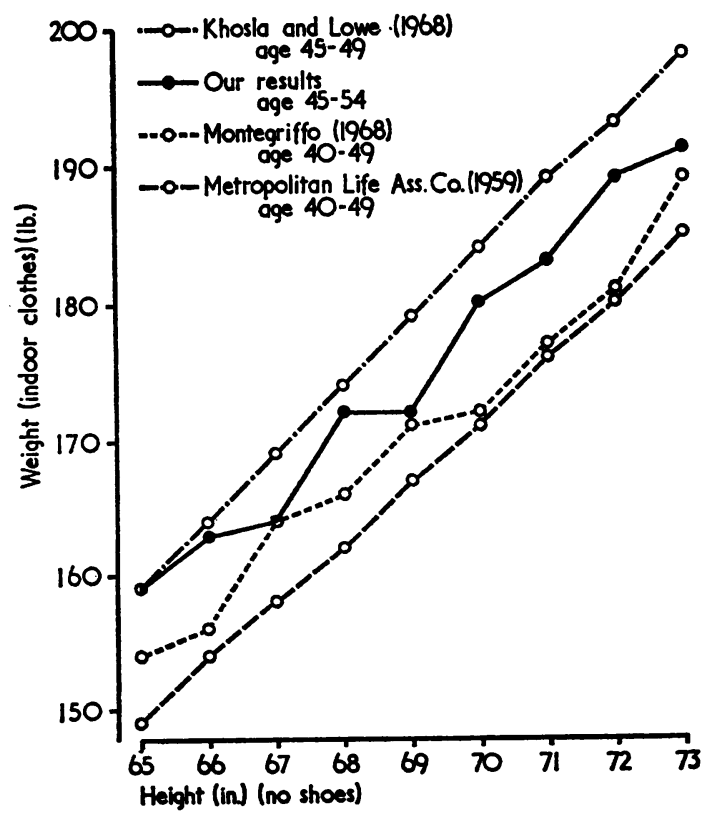

FrGURE. Weight at inches of height at ages shown. than the 'ideal weights' produced by the Metropoli$\tan$ Life Assurance Company (1959) from the United States of America, which are those associated with the lowest mortality experience. However, there is likely to be self-selection in people approaching an assurance company, bias towards certain income groups and, presumably, exclusion of high-risk cases.

It should be noted that half of our subjects came as groups of senior executives from various firms, and that the other half came personally for a checkup and advice. As a consequence the general standard of health in our series may be less than among individuals examined for life assurance. The businessmen were about $8 \mathrm{lb}$. overweight for their height, using as a reference the Metropolitan Life Assurance Company figures, adjusted for age and height, which gives some indirect support for this hypothesis.

Though based on relatively small numbers, our results suggest that the distribution of weight at different heights may vary in such a way that short persons are more likely to be overweight than tall persons. This finding, if confirmed, might account for the results claimed by Gertler and White (1954) that there is a negative correlation between increasing height and morbidity from ischaemic heart disease, in view of the well-known relationship between mortality from coronary disease and obesity (Society of Actuaries, 1959; Preston and Clarke, 1966). On the other hand, Kemsley et al. (1962) stated that they knew of no data that demonstrated the presence of a significant social class difference in the relationship of weight to height.

As we have said, although mean weight adjusted for height tended to increase steadily with age, maximum mean weight was reached at around age 45-54 and this agrees with other recent crosssectional studies. There is some evidence of a secular trend in the age of maximum weight. It seems likely 
that young men now are heavier, height for height, than in the past, though our data cannot shed any light on this as yet. It is not unreasonable to expect a population selected so strongly on occupational and other grounds to show a difference from differently selected groups.

In conclusion there is obviously a great need for longitudinal studies to clarify the interpretation of heights and weights in a period of changing social habits and to explore further the differences between social classes.

\section{SUMmaRY}

The distribution of heights and weights in over four thousand business men is presented. Mean height tends to decrease with age. Mean weight increases with height and with age, if height is allowed for. The data are compared with other published series and show our population to be generally taller. There is a suggestion that the short people in this group may be more obese than the tall.

One of us (J.R.) is in receipt of a full-time fellowship from the British Heart Foundation. We are very grateful for the advice and encouragement of Dr. H. B. Wright and Professor R. S. F. Schilling, and for statistical advice from Miss Joan Walford.

\section{REFERENCES}

AshCroft, M. T., LING, J., LOVELl, H. G., and Miall, W. E. (1966). Heights and weights of adults in rural and urban areas of Jamaica. Brit. J. prev. soc. Med., 20, 22.

Clements, E. M. B., and Pickett, K. G. (1954). Bodyweight of men related to stature, age, and social status. Ibid., 8, 99.

Evans, G. J., and Prior, I. A. M. (1969). Indices of obesity derived from height and weight in two Polynesian populations. Ibid., 23, 56.

GaRN, S. M. (1967). Nutrition Society Symposium, Nutrition and bone loss: Introductory remarks. Fed. Proc., 26, 1716.
Gertler, M. M., and White, P. D. (1954). Coronary Heart Disease in Young Adults. Harvard University Press, Cambridge, Mass.

Harrison, G. A., Weiner, J. S., Tanner, J. M., and Barnicot, N. A. (1964). Human Biology. Clarendon Press, Oxford.

Kemsley, W. F. F. (1952). Body-weight at different ages and heights. Ann. Eugen., 16, 316.

-, Blllewicz, W. J., and Thomson, A. M. (1962). A new weight-for-height standard based on British anthropometric data. Brit. J. prev. soc. Med., 16, 189.

KHosla, T., and LowE, C. R. (1967). Indices of obesity derived from body weight and height. Ibid., 21, 122.

- - (1968). Height and weight of British men. Lancet, 1, 742.

Martin, W. J. (1949). The Physique of Young Adult Males. Med. Res. Coun. Mem., No. 20. H.M.S.O., London.

Metropolitan Life Assurance Co. (1959). New weight standards for men and women. Stat. Bull., 40, Nov.Dec., p. 1.

Miall, W. E., Ashcroft, M. T., Lovell, H. G., and Moore, F. (1967). A longitudinal study of the decline of adult height with age in two Welsh communities. Hum. Biol. 39, 445.

MONTEGRIFFo, V. M. E. (1968). Height and weight of a United Kingdom adult population with a review of anthropometric literature. Ann. hum. Genet., 31, 389.

Pearson, E. S., and Hartley, H. O., ed. (1966). Tests for departure from normality. Biometrika Tables for Statisticians, 3rd ed., vol. 1, p. 67. University Press, Cambridge.

Pincherle, G., and Wright, H. B. (1967). Screening in the early diagnosis and prevention of cardiovascular diseases. J. Coll. gen. Practit., 13, 280.

Preston, T. W., and Clarke, R. D. (1966). An investigation into the mortality of impaired lives during the period 1947-63. J. Inst. Actuaries, 92, 27.

SOCIETY OF ACTUARIES. (1959). Build and Blood Pressure Study. Chicago.

TANNER, J. M. (1962). Growth at Adolescence. 2nd ed. Blackwell, Oxford.

WrIGHT, H. B. (1968). Examining the individual in relation to his environment. Bull. N.Y. Acad. Med., 44, 346. 